\title{
ANALISIS PERAN KEPEMIMPINAN CAMAT TERHADAP PEMBINAAN PEGAWAI DI KANTOR CAMAT KECAMATAN TADU RAYA KABUPATEN NAGAN RAYA
}

\author{
Sri Wahyu Handayani ${ }^{1)}$, Dina Nuraisyah ${ }^{2)}$ \\ Fakultas Ilmu Sosial dan Ilmu Politik, Universitas Teuku Umar \\ Email: sriwahyuhandayani904@yahoo.co.id
}

\begin{abstract}
.This article aims to determine the role of sub-district leadership in coaching employees in the Head Office of Tadu and the factors that influence the subdistrict governments to develop employees at Head Office Tadu. This study uses a qualitative method with purposive sampling techniques. The results of the research that leadership role in coaching employees in the Head office of the District Head Tadu Nagan Raya, has been implemented as not it should be. But basically camat is not based on a government education (SSTP), but camat was commissioned by head of district (bupati), so that the role of the sub-district leadership of the coaching employees in the sub-district office Tadu very emproyent the organization goes by. This is evident from the pattern of the services provided by employees and contract workers to the community environment of the Tadu District. Other hand, many factors that affect the role of Head of the coaching employee first because of factors have been determined based on the regulations of the district. Second, the head is obliged to foster employee. Third, the rules that head is responsible for his subordinates. Fifth,head as the initiative itself. Sixth, because of discipline and responsibility of a leader to build employee duties. Seventh,it was also due to his obligations as camat factor in fostering employee, because camat as head of the district. Eighth, due to employee discipline is highly dependent on the leadership style of the subdistrict head, so that the district head and firm discipline the employee will be disciplined. Nine, because of the factor so as to foster employee transferred to the improvement of service quality.
\end{abstract}

Keywords: Analysis, Strategy, Leadership, Head, Fostering Office 


\section{PENDAHULUAN}

Pembangunan kecamatan merupakan bagian integral dari pembangunan nasional dengan berdasarkan prinsip otonomi daerah dan pengaturannya, meningkatkan sumber daya nasional dengan memberikan kesempatan bagi peningkatan demokrasi dan kinerja pemerintah kecamatan, meningkatkan daya guna dan hasil guna bagi penyelenggaraan pemerintah, pelaksanaan pembangunan dan pelayanan kepada masyarakat, (Ndraha,1993: 27).

Mewujudkan tujuan nasional, bangsa Indonesia telah melaksanakan pembangunan nasional yang merupakan usaha perubahan yang berencana, bertahap dan berkesinambungan, meliputi seluruh aspek kehidupan masyarakat dan pelaksanaannya melibatkan pendayagunaan unsur kekuatan nasional, baik kekuatan efektif maupun potensial yang salah satunya adalah pemerintah kecamatan. Penyelenggaraan pemerintahan kecamatan memerlukan adanya pemimpin yang selalu mampu untuk menggerakkan bawahannya agar dapat melaksanakan tugas dan tanggung jawabnya untuk berpartisipasi dalam kegiatan pemerintahan, pembangunan dan kemasyarakatan secara berdayaguna dan berhasil guna. Keberhasilan pembangunan akan terlihat dari tingginya produktivitas, penduduk makmur dan sejahtera secara merata. Kondisi seperti ini tentunya tidak terlepas dari peranan seorang kepemimpinan. Pendapat seperti tersebut di atas sejalan dengan Undang-Undang Nomor 8 Tahun 1974 Tentang Pokok-Pokok Kepegawaian sebagaimana telah diubah dengan Undang-Undang Nomor 43 Tahun 1999 yang dalam penjelasannya menyatakan bahwa kelancaran penyelenggaraan tugas pemerintahan dan pembangunan nasional sangat tergantung pada kesempurnaan aparatur negara khususnya pegawai negeri. Dalam pelaksanaan berbagai aktifitas organisasi sekecil dan semodern apapun, sangat diperlukan seorang pemimpin yang kualitas dan kuantitasnya memadai dalam mengimplementasikan segenap rencana program kerja yang telah disepakati dan ditetapkan. Dalam kontek pemikiran demikian maka upaya pembinaan, pengembangan, dan peningkatan kualitas semakin menduduki peran penting dalam mewujudkan tujuan organisasi secara efisien dan efektif. Berdasarkan Undang-undang Nomor 23 Tahun 2014 tentang Pemerintahan Daerah bahwa pemerintah daerah menjadi tulang punggung dalam menggerakkan roda pemerintahan pembangunan daerah. SDM dalam suatu organisasi mempunyai peranan yang sangat penting, karena suatu tujuan dalam organisasi tersebut dapat berjalan baik atau tidaknya tergantung dari faktor manusia yang berperan, merencanakan, melaksanakan dan mengendalikan organisasi yang bersangkutan. Untuk memperoleh kemajuan dan mencapai tujuan yang telah ditetapkan. Pimpinan perlu menggerakkan pegawainya agar dapat mengembangkan seluruh kemampuan yang dimilikinya.

Usaha pengembangan dan pemanfaatan SDM sebagai aparatur pemerintah dan aset penting dalam pembangunan nasional dipandang sebagai salah satu bentuk investasi jangka panjang yang sangat strtegis serta profesional dalam upaya menjamin dan meningkatkan produktifitas kerja organisasi. Pemerintah menyadari sepenuhnya akan besarnya peran pegawai dalam menunjang keberhasilan penyelenggaraan pemerintahan dan pembangunan. Hal ini dapat dilihat dari berbagai upaya pemerintah dalam meningkatkan dan menyempurnakan kebijaksanaan pembangunan dan pendayagunaan aparat. Salah satu tujuan pokok pembinaan kepegawaian adalah terbinanya pegawai dengan tingkat disiplin kerja tinggi yang merupakan kunci keberhasilan dalam mewujudkan tugas-tugas fungsi pemerintah yang cenderung meningkat seiring perkembangan tata kehidupan segala aspek, baik dalam pengaturan, penyelenggaraan maupun dalam rangka memberikan pelayanan kepada masyarakat. Konsekuensi logis dalam hal tersebut diatas adalah bahwa pegawai harus lebih produktif, kaya akan ide-ide cemerlang, gagasan positif yang hanya akan terwujud dengan sikap disiplin dikalangan pegawai yaitu adanya sikap mental dan kesadaran diri segenap pegawai dalam pelaksanaan keseluruhan aktifitas pembangunan untuk memenuhi segenap norma-norma, ketentuan-ketentuan dan peraturan undang-undang yang berlaku dilingkungan masyarakat yang luas dan kompleks. Sehubungan dengan hal tersebut di atas, dalam rangka meningkatkan efisiensi dan efektifitas 
penyelenggaraan pemerintahan guna mendukung berbagai kebijaksanaan umum pemerintahan yang meliputi kebijaksanaan di bidang administrasi pemerintahan kecamatan. Camat sebagai penyelenggara dan penanggungjawab dibidang pemerintahan, pembangunan dan kemasyarakatan ditingkat kecamatan harus senantiasa berupaya meningkatkan prinsip terpadu, menyeluruh, berkelanjutan dan terkoordinasi terutama untuk tugas-tugas sebagai kepala wilayah kecamatan dalam meningkatkan efektifitas dan kualitas kerjanya secara optimal. Selain itu seorang camat juga harus dapat menciptakan peran serta masyarakat terhadap pelaksanaan pembangunan baik dalam bentuk material maupun non material.

Pencapaian keberhasilan pembangunan, kepemimpinan camat mempunyai peranan yang sangat penting terutama didalam merencanakan,mengembangkan, mengatur dan mengarahkan bawahannya dan seluruh potensi sumber daya yang ada sebab berapapun besarnya sumber daya serta modal yang dimiliki, kesemuanya itu tidak akan berdaya guna dan berhasil guna jika tidak didukung adanya kepemimpinan yang efektif serta kurangnya kesadaran masyarakat terhadap pelaksanaan pembangunan. Untuk lebih mengefektifkan peraturan yang telah dikeluarkan dalam rangka menegakkan disiplin, perlu adanya pembinaan teladan pimpinan, pimpinan mempunyai pengaruh yang sangat besar dalam menegakkan kedisiplinan, sebab pimpinan merupakan panutan dan sorotan dari bawahannya. Pimpinan juga harus memberi contoh yang baik. Apabila teladan pimpinan baik, kedisiplinan bawahanpun akan ikut baik. Jadi, pimpinan ikut serta dalam menciptakan kedisiplinan pegawai. Pimpinan harus mampu menggerakkan dan mengarahkan pegawai karena pimpinan bertanggung jawab terhadap keberhasilan dan kegagalan pegawai.

Dalam rangka percepatan pelaksanaan pembangunan di Kecamatan Tadu Raya peranan aparat atau pegawai pada setiap instansi maupun unit-unit kerja lainnya menduduki posisi penting sebagai motor penggerak aktifitas kerja sesuai tugas masing-masing. Namun demikian hasil pengamatan sementara manunjukkan bahwa tingkat kinerja pegawai pada Kantor Camat Tadu Raya belum menunjukkan tingkat yang maksimal. Hal tersebut terlihat dari kurang disiplinnya pegawai atas ketepatan jam masuk kerja sehingga berpengaruh pada tingkat kinerja pegawai. Belum tercapainya kinerja aparat sesuai dengan apa yang di inginkan disebabkan kurang disiplinnya aparat dalam melaksanakan tugas dan tanggung jawab sesuai dengan tupoksi yang dimiliki dan sesuai aturan-aturan yang ada dan berlaku.

Dari hasil pengamatan penulis terhadap tingkat kehadiran aparat, dimana adanya ketidak patuhan sebagian aparat terhadap aturan tata tertib seperti datang dan keluar kantor tidak sesuai waktunya dan meninggalkan kantor tanpa meminta izin kepada pimpinan sehingga berdampak pada adanya waktu lembur untuk menyelesaikan tugas-tugas ataupun pekerjaan yang tertunda. Belum maksimalnya tingkat kinerja dan masih rendahnya tingkat disiplin pegawai tersebut karena iklim pekerjaan tersebut belum mempunyai pekerjaan sesuai dengan bidang tugas atau sesuai kemampuannya. Camat sebagai pemberi layanan pemerintah kecamatan berupaya untuk lebih meningkatkan perannya agar Kecamatan Tadu Raya yang masih berumur muda tidak kalah bersaing dengan kecamatan-kecamatan lain yang sudah lama.

Dengan demikian, atas dasar pentingnya peran kepemimpinan Camat tersebut dikaitkan dengan masalah-masalah yang telah diuraikan diatas, maka penulis mengkaji lebih mendalam mengenai kepemimpinan Camat dengan mengemukakan judul dalam penelitian yaitu"Analisis Peran Kepemimpinan Camat Terhadap Pembinaan Pegawai" (Studi pada Kantor Camat Tadu Raya Kabupaten Nagan Raya).

\section{METODOLOGI PENELITIAN}

Penelitian ini menggunakan metode kualitatif Penelitian kualitatif adalah penelitian deskriptif yang bertujuan untuk membantu menjelaskan karakteristik objek dan sabjek penelitian (Arikunto, 2009: 88). Metode penelitian kualitatif adalah sebagai prosedur penelitian yang menghasilkan data deskriptif berupa kata-kata tertulis atau lisan dari orang-orang dan perilaku yang dapat diamati, Moleong Lexy, (2011: 3). Dengan dasar tersebut, maka penelitian 
ini diharapkan mampu memberikan gambaran tentang Analisis Peran Kepemimpinan Camat Terhadap Pembinaan Pegawai "Studi Kasus Kantor Camat Tadu Raya, Kabupaten Nagan Raya".

\section{HASIL PENELITIAN DAN PEMBAHASAN}

Kata peranan berasal dari kata "peran", istilah ini diambil dari dunia teater. Didalam teater seorang actor harus bermain sebagai tokoh tertentu dan posisinya sebagai tokoh tersebut ia diharapkan berperilaku secara tertentu.

Menurut Polak, peranan adalah serangkaian kegiatan yang menonjol yang dilakukan seseorang atau sekelompok orang dalam mendorong terjadinya suatu hal. Dengan demikian peranan adalah pola tindakan yang dilakukan secara individual maupun kolektif yang membawa suatu akibat atau efek (Ndraha, 1993:114).

Sedangkan kepemimpinan dapat diartikan sebagai proses mempengaruhi dan mengarahkan para pegawai dalam melakukan pekerjaan yang telah ditugaskan kepada mereka. Sebagaimana didefinisikan oleh Stoner, Freeman dan Gilbert (1995:27), Kepemimpinan adalah proses dalam mengarahkan dan mempengaruhi para anggota dalam hal berbagai aktifitas yang harus dilakukan.

Pembinaan berasal dari kata "bina" yang mendapat awalan kata"me-"menjadi kata "membina" berarti membangun, mendirikan, mengusahakan supaya lebih maju. Pembinaan adalah suatu usaha yang dilakukan dengan teratur dan terarah untuk meningkatkan pengetahuan dan sikap keterampilan objek yang dididik dengan tindakan -tindakan berupa pengarahan, bimbingan, pengembangan, stimulasi dan kepiawaian untuk mencapai tujuan yang diharapkan (S. Hidayat, 1978:26).

Menurut Undang-undang No. 23 Tahun 2014 tentang Kepegawaian Daerah, pegawai adalah mereka yang telah memenuhi syarat-syarat yang telah dipercayakan kepadanya dan telah ditentukan dalam peraturan perundang-undangan yang berlaku, diangkat oleh pejabat yang berwenang dan diserahi tugas dalam suatu jabatan Negara atau diserahi tugas Negara lainnya yang ditetapkan berdasarkan peraturan perundang-undangan yang berlaku. Pegawai adalah pelaksana undang-undang oleh sebab itu pegawai wajib berusaha untuk menaati segala peraturan perundang-undangan.

Demikian halnya dengan peran kepemimpinan camat dalam pembinaan pegawai di kantor camat Kecamatan Tadu Raya Kabupaten Nagan Raya dimana hal tersebut sangat terlihat peran seorang kepemimpinan camat dalam membina pegawainya yang terjadi selama ini, salah satu dimana seorang camat membina pegawainya agar tetap disiplin dalam melaksanakan tugas serta mengoptimalkan pelayanan kepada masyarakat.

\section{Peran kepemimpinan camat dalam pembinaan pegawai di Kantor Camat Tadu Raya}

Peran kepemimpinan sangat penting didalam sebuah organisasi maupun lembaga swasta serta lembaga pemerintahan dimana keberhasilan suatu organisasi sangat tergantung pada peranan seorang Leader yang mengarahkan dan membina bawahannya agar tujuan dan target organisasi/lembaga tersebut dapat tercapai.

Demikian halnya yang terjadi di Kecamatan Tadu Raya Kabupaten Nagan Raya, dimana peranan kepimpinan camat terhadap pembinaan pegawai di kantor Camat Tadu Raya sangat berpengaruhi pada organisasi tersebut. Hal tersebut terlihat dari yang terjadi selama ini, dimana tingkat kualitas layanan pegawai kantor kecamatan sudah terlaksana dengan baik,hal tersebut terlihat dari pola pelayanan yang diberikan oleh pegawai dan tenaga kontrak kepada para masyarakat dilingkungan Kecamatan Tadu Raya. Disisi lainnya terlihat bahwa kualitas pelayanan selama ini semuanya berjalan dengan baik terhadap kualitas pelayanan, hal tersebut karena bapak camat selalu mengarahkan para pegawai agar melayani masyarakat dengan cepat, tepat, akurat, dan baik maksimal terhadap pemberian pelayanan. 
Hal tersebut karena disiplinnya pegawai datang tepat waktu, ini salah satu peran camat dalam membina pegewai dimana bapak camat datang lebih awal dari pegawainya. Sehingga ada pegawai yang malas datang tepat waktu, dengan adanya peran camat mereka lebih awal datang minimal tepat pada waktunnya.

Demikian juga pada sisi lainnya bahwa karena peran kepimpinan camat dalam pembinaan pegawai, dimana terlihat semua tergantung setiap pekerjaan atau setiap bidang atau porsi masing-masing bidang yang di butuhkan pasti melayani pekerjaan dengan kualitas yang baik. Karena apabila tidak dikerjakan dengan baik nanti bisa ditegur oleh bapak camat ataupun bapak sekcam. Sehingga semua pekerjaan dikerjakan pada poksi masing-masing serta sesuai dengan kebu tuhan masyarakat. Hal yang demikian merupakan salah satu peran kepemimpinan camat dalam membina para pegawai. Disisi lainnya pekerjaan yang dilakukan oleh para pegawai kantor Camat Tadu Raya sudah memenuhi kualitas yang baik, terlihat salah satunya pekerjaan yang dikerjakan oleh para pegawai yang sudah ada pengalaman yaitu di dalam bidang PPAT dan bidang pembuatan ktp, akte dan sebagainya.

Berdasarkan pembahasan diatas dapat diambil kesimpulan bahwa peran kepemimpinan camat dalam pembinaan pegawai di kantor camat Kecamatan Tadu Raya Kabupaten Nagan Raya, sudah terlaksanakan sebagaimana mestinya peran seorang camat. Hal tersebut terlihat dari roda pemerintahan yang berjalan dikantor camat Kecamatan Tadu Raya,dimana peran kepimpinan camat terhadap pembinaan pegawai di kantor Camat Tadu Raya sangat berpengaruhi pada organisasi tersebut. Hal tersebut terlihat dari yang terjadi selama ini, dimana Tingkat kualitas layanan pegawai kantor kecamatan sudah terlaksana dengan baik, hal tersebut terlihat dari pola pelayanan yang diberikan oleh pegawai dan tenaga kontrak kepada para masyarakat dilingkungan Kecamatan Tadu Raya.

Disisi lainnya terlihat bahwa kualitas pelayanan selama ini semuanya berjalan dengan baik terhadap kualitas pelayanan, hal tersebut karena bapak camat selalu mengarahkan para pegawai agar melayani masyarakat dengan cepat, tepat, akurat, dan baik maksimal terhadap pemberian pelayanan.

Hal tersebut karena disiplinnya pegawai datang tepat waktu, ini salah satu peran camat dalam membina pegewai dimana bapak camat datang lebih awal dari pegawainya. Sehingga ada pegawai yang malas datang tepat waktu, dengan adanya peran camat mereka lebih awal datang minimal tepat pada waktunnya. Demikian juga pada sisi lainnya bahwa karena peran kepimpinan camat dalam pembinaan pegawai, dimana terlihat semua tergantung setiap pekerjaan atau setiap bidang atau porsi masing-masing bidang yang di butuhkan pasti melayani pekerjaan dengan kualitas yang baik.

Apabila tidak dikerjakan dengan baik nanti bisa ditegur oleh bapak camat ataupun bapak sekcam. Sehingga semua pekerjaan dikerjakan pada poksi masing-masing serta sesuai dengan kebutuhan masyarakat. Hal yang demikian merupakan salah satu peran kepemimpinan camat dalam membina para pegawai. Hal-hal diatas terjadi merupakan bagian dari peran kepempinan camat dalam membina pegawai.

\section{Faktor-faktor apa yang mempengaruhi peran camat terhadap pembinaan pegawai di Kantor Camat Tadu Raya.}

Banyak faktor yang menpengaruhi seorang pemimpin dalam menjalankan sebuah kepemimpinan, dimana faktor tersebut bisa disebabkan oleh dua jenis faktor yaitu faktor yang berasal dari dalam (internal) seorang pemimpin itu sendiri dan faktor yang berasal dari luar (eskternal) seorang pemimpin itu sendiri.

Dimana faktor-faktor tersebut sangat berpengaruh pada peran seorang pemimpin didalam memimpin suatu wadah organisasi atau suatu lembaga baik itu swasta maupun pemerintah. Salah faktor yang berpengaruh yang berasal dari dalam pemimpin itu biasa tegas, disiplin dan lugas. Sedangkan dari luar salah satu karena faktor aturan yang mengikat sehingga itu sangat 
mempengaruhi diri dalam memainkan perannya termasuk pada pembinaan bawahan baik itu pegawai maupun tenaga kontrak ataupun honorer.

Demikian juga dengan yang terjadi di Kecamatan Tadu Raya Kabupaten Nagan Raya, dimana banyak faktor yang mempengaruhi peran camat terhadap pembinaan pegawai di Kantor Camat Tadu Raya tersebut. Dimana hal tersebut dipengaruhi oleh berbagaimacam faktor yang mempengaruhinya. Salah satu karena faktor sudah ditentukan dan di arakan dari peraturanperaturan dikabupaten. Kedua karena faktor camat memang wajib membina pegawai, hal itu karena beliau merupakan seorang perpanjangan tangan bupati untuk ditingkat kecamatan, jadi segala sesuatu keputusan ada ditangan camat.

Namun disisi lainnya salah satu karena faktor ia bekerja dan itu sangat tergantung bagaimana camatnya. Kedua karena faktor peraturan bahwa camat bertanggung jawab terhadap bawahannya, ketiga karena faktor inisiatif camat itu sendiri. Tidak terlepas dari itu saja ada juga karena factor kedisiplinan seorang camat yang cukup baik, sehingga mempengaruhi para pegawai yang lain untuk disiplin dan tidak berani untuk main-main didalam bekerja. Kedua memang karena faktor tanggung jawab seorang camat untuk membina pegawai dilingkungan tugasnya.

Hal yang demikian juga disebabkan oleh faktor kewajiban beliau sebagaicamat dalam membina pegawai, karena camat sebagai pimpinan kecamatan, seorang camat memang harus membina pegawai, jika bapak camat tidak membina pegawai kemungkinan besar bapak camat kursi panjang atau dipindah karena dianggap gagal memimpin kecamatan tersebut. Kemudian karena faktor kedisiplinan pegawai sangat tergantung pada gaya kepemimpinan camat, jadi kalau camat disiplin dan tegas maka pegawai juga akan disiplin. Selain faktor tersebut juga dipengaruhi oleh faktor diantaranya karena faktor takut dimutasi sehingga membina pegawai terhadap peningkatan mutu pelayanan, memang betul adanya takut dimutasi.

Berdasarkan pembahasan diatas dapat diambil kesimpulan bahwa, selama ini banyak faktor yang mempengaruhi peran camat terhadap pembinaan pegawai dikantor camat Kecamatan Tadu Raya, adapun faktor-faktor tersebut sangat berpengaruh pada peran camat. Salah satu karena faktor sudah ditentukan dan diarakan dari peraturan-peraturan dikabupaten. Kedua karena faktor camat memang wajib membina pegawai, hal itu karena beliau merupakan seorang perpan jangan tangan bupati untuk ditingkat kecamatan, jadi segala sesuatu keputusan ada di tangan camat.

Namun disisi lainnya karena faktor ia bekerja dan itu sangat tergantung bagaimana camatnya. Kedua karena faktor peraturan bahwa camat bertanggung jawab terhadap bawahannya, ketiga karena faktor inisiatif camat itu sendiri. Kemudian karena factor kedisiplinan seorang camat yang cukup baik, sehingga mempengaruhi para pegawai yang lain untuk disiplin dan tidak berani untuk main-main didalam bekerja, serta karena faktor tanggung jawab seorang camat untuk membina pegawai dilingkungan tugasnya.

Hal yang demikian juga disebabkan oleh faktor kewajiban beliau sebagai camat dalam membina pegawai, karena camat sebagai pimpinan kecamatan. Kemudian karena faktor kedisiplinan pegawai sangat tergantung pada gaya kepemimpinan camat, jadi kalau camat disiplin dan tegas maka pegawai juga akan disiplin, serta karena faktor takut dimutasi sehingga membina pegawai terhadap peningkatan mutu pelayanan, memang betul adanya takut dimutasi.

Dimana selama ini faktor-faktor tersebutlah selama ini yang sangat mempengerahui peran camat dalam pembinaan pegawai dikantor Camat Kecamatan Tadu Rayu Kabupaten Nagan Raya.

\section{Tanggapan Pegawai dan Masyarakat Terhadap Terhadap Peran Kepemimpinan Camat di Dalam Membina Pegawai di Kantor Camat Tadu Raya}

Penelitian ini dilakukan di kecamatan Tadu Raya Kabupaten Nagan Raya Provinsi Aceh. Keberhasilan seorang pemimpin dalam suatu instansi ataupun suatu lembaga sangatlah 
tergantung pada gaya seorang pemimpin didalam memimpin bahawannya untuk mencapai target suatu tujuan dari suatu lembaga tersebut. Seorang pimpinan bertanggung jawab penuh terhadap bawahannya agar selalu disiplin didalam bekerja. Demikian halnya dengan Kecamatan Tadu Raya dimana dipimpin oleh seorang camat, dimana camat didalam kesehariannya beliau harus memimpin bawahannya agar tetap disiplin dalam bekerja sesuai dengan tugas dan fungsi masing-masing para pegawainya.

Seorang camat sangatlah dituntut untuk memberikan peran penting terhadap kemajuan suatu daerah dimana ia ditugaskan, termasuk masalah pembinaan para pegawai. Dalam hal ini camat Kecamatan Tadu Raya sudah berperan penting dalam membina para pegawainya. Pegawai dibina untuk memberikan pelayanan kepada masyarakat secara menyeluruh, agar kebutuhan masyarakat dapat terpenuhi terpenuhi terutama dalam urusan yang bersifat pemerintahan dan sebagainya.

Tingkatan Kualitas Layanan Pegawai Kantor Kecamatan sudah Terlaksana Dengan Baik.

Berdasarkan jawaban informan tingkatan kualitas layanan pegawai kantor kecamatan sudah terlaksana dengan baik, hal tersebut terlihat dari pola pelayanan yang diberikan oleh pegawai dan tenaga kontrak kepada masyarakat dilingkungan Kecamatan Tadu Raya.

Disisi lainnya terlihat bahwa kualitas pelayanan selama ini semuanya berjalan dengan baik terhadap kualitas pelayanan, hal tersebut karena bapak camat selalu mengarahkan para pegawai agar melayani masyarakat dengan cepat, tepat, akurat, dan baik maksimal terhadap pemberian pelayanan.

Salah satunya karena pengaruh disiplinnya pegawai datang tepat waktu, ini salah satu peran camat dalam membina pegawai dimana bapak camat datang lebih awal dari pegawainya. Sehingga ada pegawai yang malas datang tepat waktu, dengan adanya peran camat mereka lebih awal datang minimal tepat pada waktunya.

Hal tersebut berbeda dari sebelumnya dimana para pegawai kurang disiplin, kurang transparansi. Sehingga kualitan pelayanan yang diberikan kepada masyarakat selama ini sangat nampak kurang bagus. Salah satunya terlihat banyak yang duduk saja dari pada kerja untuk melayani masyarakat.

\section{Pekerjaan yang dilakukan oleh para pegawai kantor camat tadu raya sudah memenuhi kualiatas yang baik.}

Berdasarkan beberapa jawaban informan dapat disimpulkan bahwa pekerjaan yang dilakukan oleh para pegawai kantor Camat Tadu sudah memenuhi kualitas yang baik, hal tersebut terlihat semua tergantung setiap pekerjaan atau setiap bidang/porsi masing-masing bidang yang membutuhkan pasti melayani pekerjaan dengan kualitas baik. Karena apabila tidak dikerjakan dengan baik nanti bisa ditegur oleh bapak camat ataupun bapak sekcam. Sehingga semua pekerjaan dikerjakan pada poksi masing-masing serta sesuai dengan kebutuhan masyarakat. Hal yang demikian merupakan salah satu peran kepemimpinan camat dalam membina para pegawai. Disisi lainnya pekerjaan yang dilakukan oleh para pegawai kantor Camat Tadu Raya sudah memenuhi kualitas yang baik, terlihat salah satunya pekerjaan yang dikerjakan oleh para pegawai yang sudah ada pengalaman yaitu dalam bidang PPAT dan bidang pembuatan ktp, akte dan sebagainya.

Hal tersebut selama ini pekerjaan dikerjakan oleh pegawai yang sudah ada kemampuan dibidangnya, hal ini ditunjukkan dengan terpenuhinya semua pelayanan baik publik administrasi yang baik. Sehingga masyarakat yang ada keperluan tetap dilayani sesuai dengan kebutuhan masing-maasing masyarakat, misalnya semacam mengurus akte tanah dikerjakan oleh bidangnya, pembuatan surat pindah dikerjakan oleh bidangnya dan sebagainya. 


\section{Penyelesaian tugas dan fungsi pegawai pada kantor Camat Tadu Raya sudah Menurut Standar Mutu Kualitas}

Berdasarkan beberapa jawaban informan diatas dapat disimpulkan bahwa,penyelesaian tugas dan fungsi pegawai pada kantor camat tadu raya sudah menurut standar mutu kualitas,karena selama ini penyelesaian dari setiap tugas dan fungsi pegawai sudah berstandar mutu kualitasnya dan sudah dilaksanakan apa adanya serta sudah sesuai dengan standar kabupaten. Hal tersebut ditunjukan dengan kinerja pegawai berdasarkan arahan dan bimbingan serta binaan dari bapak camat. Namun disisi lainnya standar operasional prosedurnya/s.o.p nya ada masing-masing setiap bidang masing-masing, sehingga tidak akan berubah standar tugas dan fungsinya pegawai. Hal tersebut diatas menunjukkan bahwa selama ini camat sudah sangat berperan di dalam membina pegawai, karena selama ini pelayan yang diberikan oleh pegawai kepada masyarakat berdasarkan arahan dari bapak camat, artinya bahwa selama ini bapak camat sudah memainkan peran kempimpinannya didalam membina pegawai yang ada di kantor camat Kecamatan Tadu Raya,Kabupaten Nagan Raya.

\section{Tanggapan Masyarakat dan Pegawai Terhadap Faktor-Faktor apa Yang Mempengaruhi Peran Camat Terhadap Pembinaan Pegawai di Kantor Camat Tadu Raya.}

Penelitian ini dilakukan di kantor Camat Kecamatan Tadu Raya Kabupaten Nagan Raya Provinsi Aceh. Banyak faktor yang mempengaruhi seorang pemimpin dalam membina pegawainya, termasuk peran camat di Kecamatan Tadu Raya dalam membina pegawai. Dimana seorang camat banyak faktor yang mempengaruhinya didalam membina para pegawai, salah satu faktor tersebut yaitu karena tanggung jawab dan aturan yang menjadi landasan awal seorang camat membina pegawai, termasuk pada camat di Kecamat Tadu Raya. Dimana kewajiban dan tanggung jawab seorang serta ada aturan yang mengatur bahwa seorang camat membina pegawai dilingkungannya, sehingga camat harus mematuhi terhadap apa yang sudah menjadi beban bagi tugas dan fungsi seorang camat dalam membina pegawai, salah satu faktor tersebut diatas yang mempengaruhi faktor peran Camat terhadap pembinaan pegawai di Kantor Camat Tadu Raya.

Dimana kewajiban dan tanggung jawab seorang serta ada aturan yang mengatur bahwa seorang camat membina pegawai dilingkungannya, sehingga camat harus mematuhi terhadap apa yang sudah menjadi beban bagi tugas dan fungsi seorang camat dalam membina pegawai, salah satu faktor tersebut diatas yang mempengaruhi faktor peran Camat terhadap pembinaan pegawai di Kantor Camat Tadu Raya.

\section{Faktor apa aja yang mempengaruhi camat dalam membina pegawai di Kantor Camat Tadu Raya.}

Berdasarkan beberapa jawaban informan diatas dapat disimpulkan bahwa banyak faktor yang mempengaruhi camat dalam membina para pegawai di kantor Camat Tadu Raya, hal tersebut salah satu pertama karena faktor sudah ditentukan dan di arakan dari peraturanperaturan dikabupaten. Kedua karena faktor camat memang wajib membina pegawai, hal itu karena beliau merupakan seorang perpanjangan tangan bupati untuk ditingkat kecamatan, jadi segala sesuatu keputusan ada dicamat.

Namun disisi lainnya salah satu karena faktor ia bekerja dan itu sangat tergantung bagaimana camatnya. Kedua karena faktor peraturan bahwa camat bertanggung jawab terhadap bawahannya, ketiga karena faktor inisiatif camat itu sendiri. Tidak terlepas dari itu saja ada juga karena factor kedisiplinan seorang camat yang cukup baik, sehingga memp engaruhi para pegawai yang lain untuk disiplin dan tidak berani untuk main-main didalam bekerja. Kedua memang karena faktor tanggung jawab seorang camat untuk membina pegawai dilingkungan tugasnya. 
Ada faktor yang lebih penting terhadap seorang camat dapat membina para pegawai salah satunya pertama karena faktor kepemimpinan atau faktor gaya kepemimpinan, kedua karena faktor pendidikan yang dimiliki oleh camat, ketiga karena faktor fransperansi, dan keempat karena faktor inisiatif seorang camat.Sehingga selama ini faktor tersebut yang telah mempengaruhi Camat Tadu Raya dalam membina para pegawai di kecamatan tersebut.

\section{Karena faktor kewajiban beliau sebagai camat dalam membina pegawai}

Berdasarkan beberapa jawaban informan diatas dapat disimpulkan bahwa,karena faktor kewajiban beliau sebagai camat dalam membina pegawai, salah satunya terlihat dari faktor kewajiban camat atau seorang camat sebagai pimpinan kecamatan,seorang camat memang harus membina pegawai, jika pak camat tidak membina pegawai kemungkinan besar pak camat kursi panjang atau dipindah karena dianggap gagal memimpin kecamatan tersebut.Namun hal tersebut juga ada faktor lainnya dimana faktor kedisiplinan pegawai sangat tergantung pada gaya kepemimpinan camat, jadi kalau camat disiplin dan tegas maka pegawai juga akan disiplin, karena beliau takut akanteguran dari pak camat. Sehingga selama ini seorang membina pegawai dilingkungan kantor camat karena dipengaruhi oleh faktor kewajiban seorang camat dalam membina pegawai dan hal tersebut sudah dilak sanakan oleh seorang camat, meskipun ada kendala realisasinya.

\section{Karena faktor takut dimutasi sehingga membina pegawai terhadap peningkatan mutu pelayanan}

Berdasarkan beberapa jawaban informan diatas dapat disimpulkan bahwa,karena faktor takut dimutasi sehingga membina pegawai terhadap peningkatan mutu pelayanan, memang betul adanya takut dimutasi. Hal tersebut terlihat darimemang karena faktor takut dimutasi, sehingga camat membina pegawainya terhadap peningkatan mutu pelayanan. Karena apabila tidak membina pegawai dia pasti dimutasi ketempat lain.

Sehingga hal ini menjadi salah satu alasan ataupun faktor kenapa camat membina pegawai. Hal yang demikian terlihat dari fakta yang terjadi selama ini memang karena faktor takut dimutasi, sehingga camat membina pegawainya terhadap peningkatan mutu pelayanan. Karena apabila tidak membina pegawai dia pasti dimutasi ketempat lain. Haini menjadi salah satu faktor kenapa camat membina pegawai. Namun itu bukan faktor juga takut dimutasi lalu membina pegawai, itu tergantung pada yang bersangkutan ( Pak Camat),tetapi itu membina pegawai merupakan faktor tanggung jawab atasan kepada bawahan. Jadi itu sebabnya kenapa camat harus membina pegawai.

\section{SIMPULAN DAN SARAN}

\section{A. Simpulan}

Setelah melakukan penelitian maka dapat diambil kesimpulan secara umum terhadap "analisis peran kepemimpinan camat terhadap pembinaan pegawai studi kasus kematan tadu raya kabupaten nagan raya", dimana dengan kesimpulan sebagai berikut:

Pertama, Bahwa peran kepemimpinan camat dalam pembinaan pegawai di kantor camat kecamatan tadu raya kabupaten nagan raya. Namun pada dasarnya kepemimpinan camat tersebut bukan berdasarkan pada sekolah setingkat tinggi pemerintahan (SSTP), akan tetapi camat tersebut ditugaskan oleh bapak bupati sebagai perpanjangan tangan untuk berjalannya roda pemerintahan di tingkat kecamatan, sehingga peran kepemimpinan camat terhadap pembinanaan pegawai di kantor camat tadu raya sangat mempengaruhi berjalannya organisasi tersebut. Hal yang demikian terlihat dari yang terjadi selama ini, dimana tingkat kualitas pelayanan pegawai dikantor kecamatan sudah terlaksana dengan baik, hal ini terlihat dari pola pelayanan yang diberikan oleh pegawai dan tenaga kontrak kepada masyarakat dilingkungan kecamatan tadu raya. Demikian juga pada sisi lainnya bahwa peran kepemimpinan camat dalam 
pembinaan pegawai, dimana terlihat semua tergantung setiap pekerjaan atau setiap pekerja atau setiap bidang/porsi masing-masing bidang yang dibutuhkan pasti melayani pekerjaan dengan kualitas yang baik. Karena apabila tidak dikerjakan dengan baik nanti bisa ditegur oleh bapak camat ataupun bapak sekcam. Sehingga semua pekerjaan dikerjakan pada poksi masing-masing serta sesuai dengan kebutuhan masyarakat. Hal yang demikian merupakan salah satu peran kepemimpinan camat dalam membina para pegawai. Hal-hal diatas terjadi merupakan bagian dari peran kepemimpinan camat dalam membina pegawai.

Kedua, Bahwa selama ini banyak faktor yang mempengaruhi peran camat terhadap pembinaan pegawai dikantor camat kecamatan tadu raya. adapun faktor-faktor tersebut sangat berpengaruh pada peran camat. Pertama karena faktor sudah ditentukan berdasarkan peraturanperaturan di kabupaten. Kedua karena camat memang wajib membina pegawai. Hal itu karena beliau merupakan seorang perpanjangan tangan bupati untuk tingkat kecamatan. Ketiga karena faktor peraturan bahwa camat bertanggung jawab terhadap bawahannya. Keempat karena inisiatif camat itu sendiri. Kelima karena faktor kedisiplinan seorang camat yang cukup baik, sehingga mempengaruhi para pegawai yang lain untuk disiplin dan tidak berani untuk mainmain didalam bekerja. Keenam karena faktor tanggungjawab seorang camat untuk membina pegawai dilingkungan tugasnya. Ketujuh juga disebabkan oleh faktor kewajiban beliau sebagai camat dalam membina pegawai, karena camat sebagai pimpinan kecamatan. Kedelapan karena faktor kedisiplinan pegawai sangat tergantung pada gaya kepemimpinan camat, jadi kalau camat disiplin dan tegas maka pegawai juga akan disiplin. Sembilan karena faktor takut dimutasi sehingga membina pegawai terhadap peningkatan mutu pelayanan, memang betul adanya takut mutasi. Dimana selama ini faktor-faktor tersebutlah selama ini yang sangat mempengaruhi peran camat dalam pembinaan pegawai dikantor camat kecamatan tadu raya kabupaten nagan raya.

\section{B. Saran}

Semoga tulisan ini menjadi pertimbangan pihak terkait Bupati kabupaten nagan raya, camat kecamatan tadu raya, masyarakat khususnya terhadap analisis peran kepemimpinan camat terhadap pembinaan pegawai studi kasus kecamatan tadu raya kabupaten nagan raya sehingga peran kepemimpinan camat tetap terjaga didalam memberikan pelayanan kepada masyarakat secara berkesinambungan demi mewujudkan masyarakat pelayanan publik yang baik.

\section{REFERENSI}

Arikunto, Suharsimi. 2009. Manajemen Penelitian. Rieneka Cipta. Jakarta.

Basrowi \& Suwandi. 2008. Memahami Penelitian Kualitatif. Rineka Cipta. Jakarta

Burhan Bungin. 2008. Metode Penelitian Kuantitatif: Komunikasi, Ekonomi, dan Kebijakan Publik Serta Ilmu-Ilmu Sosial Lainnya. Kencana. Jakarta.

Chinoy. 1993. Peranan Kepemimpinan. Balai Pustaka. Jakarta

Depdiknas. 2002. Kamus Besar Bahasa Indonesia Edisi Ketiga. Balai Pustaka. Jakarta.

Dr. W.A. Gerungan, 1997. Tipe-tipe Kepemimpinan. Balai Pustaka. Jakarta

Dr. W.A. Gerungan, 1997. Ciri Kepemimpinan. Balai Pustaka. Jakarta

Griffin, 2000. Kepemimpinan. Balai Pustaka.Jakarta

Hanton dan Hunt. 1999. Konsep Pera. Rineka Cipta. Jakarta

Hosking. 1988. Pemimpin. Balai Pustaka. Jakarta

Juliansyah Noor. 2011. Metodelogi Penelitian: Skripsi, Tesis, Disertase, dan karya Ilmiah. Edisi

Pertama. Kencana Prenada Media Group. Jakarta

Jacob \& Jacques. 1990. Kepemimpinan. Balai Pustaka. Jakarta

Koentjaraningrat. 2004. Pengantar Antropologi Jilid I . Rineka Cipta. Jakarta

Katz \& Kahn. 1978. Kepemimpinan. Rineka Cipta. Jakarta 
Kriyantono, Rachmat. 2007. Teknik Praktis Riset Komunikasi: Di Sertai Contoh Praktis Riset Media, Public Relation, Advertising, Komunikasi Organisasi, Komunikasi Pemasaran, Ed I, cet. Kedua. Kencana. Jakarta

Kamus Bahasa Indonesia online//www.KamusBahasaIndonesia.org). diakses Tanggal 23Juni 2016

Moleong, Lexy J. 2011. Metodologi Penelitian Kualitatif. Remaja Rosdakarya. Bandung

Moleong, Lexy J. 2002. Metodologi Penelitian Kualitatif. Remaja Rosydakarya.Bandung

Musanef, 1995. Konsep Pegawai Dalam Pemeritahan. Balai Pustaka. Jakarta

Musanef, 2000. Konsep Pembinaan Pegawai. Remaja Rosydakarya. Jakarta

Masson, 1997. Konsep peranan sebagai seperangkat harapan-harapan yang dikenakan pada individu yang menempati kedudukan sosial tertentu.Kencana Prenada Media Group. Jakarta

Miles dan Huberman. 1984. Metode Analisis. Balai Pustaka. Jakarta

Ndraha. 1993. Peran-Peran dalam Organisasi Kepemimpinan. Prenanda Media Group. Jakarta

Poerwadarmita. 2003. Pembinaan adalah suatu usaha, tindakan dan kegiatan yang dilakukan secara berdaya guna. Rajawali Pers. Jakarta

Polak. 1992. Peranan Kepemimpinan. Rineka Cipta. Jakarta

Stoner, Freeman dan Gilbert. 1995. Kepemimpinan. Rineka Cipta. Jakarta

Soekanto. 1990. Peran adalah aspek dinamis dari kedudukan (status).LP3ES. Jakarta

S.Hidayat. 1978. Pembinaan, pengarahan, bimbingan, pengembangan, stimulasi dan kepiawaian. Rajawali Pers. Jakarta

Sudjana. 2004. Pembinaan yaitu sebagai rangkaian upaya pengendalian secara professional terhadap semua unsure-unsur. Rineka Cipta. Jakarta

Stogdill. 1974. Kepemimpinan struktur dan interaksi. Raja Grafinda Persada. Jakarta

Sugiyono. 2011. Metode Penelitian Kuantitatif dan Kualitatif $R$ \& D. CV Alfabeta. Bandung

Scott et al. 1981. Dalam Kanfer,1987. Konsep Peran. Raja Grafindo Persada. Jakarta

Rauch \& Behling. 1984. Kepemimpinan dan pencapaian tujuan organisasi. Rajawali Pers. Jakarta

Tannenbaum, Weschler \& Massarik. 1961. Kepemimpinan. Remaja Rosdakarya. Jakarta

Thoha. 2001. Konsep Pembinaan adalah suatu proses, hasil atau pertanyaan menjadi lebih baik, dalam hal ini mewujudkan adanya perubahan. Remaja Rosydakarya. Bandung

Undang-undang Nomor 23 Tahun 1999 tentang Pokok-pokok Kepegawaian

Undang-undang No. 32 Tahun 2004 tentang Kepegawaian Daerah

Wijaya, 1996. Konsep Pegawai dalam Pemeritahan. Balai Pustaka. Jakarta

Yukl, 1994. Pengaruh Kepemimpinan. Balai Pustaka. Jakarta 